\title{
The past of dreams: gender, memory and Tuareg oneiric inspiration
}

\author{
Amalia Dragani
}

\section{Introduction}

This article is built upon both an observation and a paradox. The observation is that the dream is nowhere to be found - at least at first glance - as a theme in Tuareg oral sources and poetic tradition, even though its presence is widespread as a topos in African literary tradition as a whole (Constant 2008). The paradox expresses itself in the visceral relationship poets maintain with the dream, because oneiric inspiration - from the creative and visionary dreams of poets of the past - is pervasive in their work.

Using an interdisciplinary approach at the crossroads of psychological anthropology, oral history and the 'archival turn' (Stoler 2009), this article explores the theme of the dream in Tuareg historical sources and its relation to contemporary gendered and oneiric practices. Why does this theme - absent from most poetry by male authors, who seem to prefer the literary evocation of insomnia - emerge in the rare examples of women's poetry that have surfaced or have been gathered? Is it that oneiric practices, associated with the world of the dead, spirits and sexuality, are typically perceived as a 'women's issue'? The ethnographic data presented here have been collected in the pays touareg since 2004: in Northern Niger (2004-07), in Northern Mali and Southern Algeria (2009-11), in the diaspora in France (since 2007) and among refugees in West African cities (Dakar, Niamey) since 2014.

This article intends to cast light on the 'nocturnal' worlds of the Tuareg, aspects of Tuareg culture that are somewhat underrepresented in the ethnographic literature. It will attempt not only to describe oneiric material gathered in different epochs, as well as to share direct observation carried out while the subjects were sleeping, but also to consider practices linked to the local meanings of, and attitudes towards, night, sleep and oneiric inspiration.

Situated on the frontier between the individual and the societal collective, the dream is a classic object in the history of anthropology (Bastide 1972; Caillois and von Grunebaum 1966; D’Andrade 1962; Devereux 1951; Lévy-Bruhl 1935; Radin 1936) and it continues to intrigue contemporary researchers, as witnessed by the number of recent books and articles on the subject (Glowczewski 2016 [1989]; Tedlock 1987; cf. Kennedy and Lagness 1981).

Vectors of practices and plural knowledge such as oneiromantic, dreams receive special attention in African traditions; this can be seen both in the frequency with which they are evoked and through the importance accorded to their

\footnotetext{
Amalia Dragani holds a PhD in social anthropology and ethnology from the École des Hautes Études en Sciences Sociales (EHESS) and is at the Laboratoire d'Anthropologie Sociale Collège de France. Email: amalia.dragani@ehess.fr
} 
interpretation as applied to daily life on an individual and collective scale, as much on the African continent itself as among the diaspora community. While the following list is not exhaustive, the qualities and powers attributed to dreams include the magical, therapeutic, medicinal, religious and prophetic. This honoured place has produced a vast, varied and fecund literature on Africa (Crapanzano 1975; Kilborne 1981; Mbembe 1991; Pype 2011). In studies of both oral and written literature, the dream transformed into accounts and narratives occupies a privileged place, not to mention the role it plays as an instigator in the creative process itself (Dragani 2012; 2016). Furthermore, numerous Africanist anthropologists, including Michel Leiris, Michael Jackson and Paul Stoller, have shared the dreams that they themselves have had in the field.

Anthropological studies of the dreams of the Tuareg have been limited to a 'dream key' based on twenty-two dreams gathered by Charles de Foucauld (de Foucauld and Motylinski 1984 [1922]), two reported by Casajus (1989), some references to herbalists' dreams and an article by Susan Rasmussen (Rasmussen 2006; 2015), as well as oneiric material resulting from my own fieldwork linked to the lives of poets and violinists (Dragani 2012; 2016).

According to de Foucauld, in tahaggart (the dialect spoken in the Ahaggar; in northern Niger, this is referred to as tayart) the dream is called tahârgit (plural: tihourga) and the action of dreaming harget. In Niger, our informants label the dream tergit and the nightmare sirumma. My investigations with Malian Tuareg have brought to light details that have not emerged in prior definitions: the word tergit signifies both 'dream' and 'nocturnal pollution'. The reference to desire, sexual dreams and the obscene shows us how much it is considered taboo to verbalize the dream in the contemporary Tuareg world.

Oral poetry also provides a source for historical research and for constructing a social history of dreams. Numerous poems produced by ancient Tuareg societies are preserved in de Foucauld's anthology, along with brief biographies of the poets. The oldest of these dates from around the end of the eighteenth century; numerous others were written in the middle of the nineteenth century; and the majority are contemporaneous with de Foucauld's stay in the Ahaggar, which ended with his death in 1916.

My research into dreams benefits not only from earlier contributions that developed an anthropology of dreams and their narrations as communicative events (Tedlock 1987) and from research into oral tradition, but also from earlier work that addressed the 'history of dreams' (Burke 1973; Beradt 1985; Lavie and Kaminer 2001; Schmitt 2003; Rechtman 1993; Wilmer 2001). In the present, in order to reconstruct African history, numerous historians look not only to official archives but also to heteroclite sources. Among these non-canonical sources one finds not only objects, photographs, music and rumours (Nativel 2011; White 2000) but also dream narrations, which 'incorporate' everyday life events. Long considered immutable and not subject to change, and associated by Freud and Jung with myths, dreams have now been historicized in order to better understand and reconstitute their socio-cultural contexts in the larger sense.

In this article, I demonstrate how a veritable silence in the sources - that is, the assumption that the dream does not seem to be a theme of poetry - can be examined through the prism of an ethnographic practice that casts light on the 'genderspecific' social usages of the dream in this society. 


\section{The past of dreams: insomnia and gender in historical and literary sources}

A discussion of how the dream is articulated into words in historic and literary Tuareg sources related to dreams, some dating as far back as the end of the eighteenth century, is of use here. The search for dream material in poetic texts is often a fruitless task since the dream is absent both in poetry and folk tales, except for rare cases that will be discussed here.

While some examples of erotic poetry and obscene songs are documented among the Tuareg, the dream is notably missing from the Tuareg literary canon. What has survived is constituted in large part by the poems of male authors, more likely to be characterized by insomnia and peopled with demonic figures than drawn directly from dreams.

Insomnia can be produced by amorous obsessions but also by anxieties linked to material subsistence, as can be seen in perusing the texts. In the following poem by Elkhasen agg Ikki des Kel Amedjid (1830-1894), while off to look for dates in the Tidipour to feed the women of his family, he addresses his thoughts to his wife:

When I passed into the valley of Ti-n-tamat, I said in my interior to Tenanegh [his wife]: The night is coming; I'm going to look for the camels.

Tenanegh, sleep will not come to me (because the thought of you is ever-present)

I utter 'ho-ho' [a Tuareg exclamation expressing sadness] as I sigh, and I readjust the veil of my forehead as if she is really in front of me.

The women that I left behind me and who are in front of me

Look at me as at their lives. [They depend on him and on the food that his journey will bring them for their survival.]

Epic poems recount episodes of vigils preceding combat. The following description of Izerouan's night of insomnia before his combat against the Ioullimeden was left to us by Mokhammed ag Mekhiia (born in 1870, and a contemporary of Charles de Foucauld when he was collecting his verses). In this poem dating from 1897, the author's insomnia is induced not by impending battle, but amorous torment:

I who tremble with pain, and in whom the heart has been torched by a fire

I was unable to sleep

Until the moment that I saddled my young camel

With a double-barrelled shotgun and my shield which never leaves me.

(Casajus 1997: 256)

Other poems suggest more explicitly that this insomnia is caused by a spirit or by Satan, a theme recurrent in Tuareg poetry and amply reprised in contemporary guitar singing, a genre called al guitara that appeared in the late 1970s.

The theme of the dream is present in women's poetry, rare examples of which have survived thanks to Charles de Foucauld, who finished compiling his anthology of Tuareg poetry three days before his death in 1916. It was published in two volumes, in 1925 and 1930.

The author of the following is the woman poet Tâti oult Ourzîg (1795-1865), a member of the Taïtoq (a Tuareg group), which pursued their nomadic circuit 
between the Ahaggar and the Aïr, that is, in the territory situated today on the frontier between Niger and Algeria. This poem, 'Lying Dream', was likely written around 1820:

Last night I dreamt of Aghenennas [her beloved's camel],

My eyes saw him shackled in the middle of camels.

When I woke up in the morning, I hiked to the summit

of a small dune, to see if he'd arrived;

My dream was revealed as a liar, the suffering of love tormented me;

An accursed burn was inflicted on my heart; may my mother and the mother of my mother perish!

(Casajus 1997: 182)

This poem conveys one of the most pervasive themes in women's literature: the vigil for the return of a man who has parted on a looting raid, with a caravan, or to a livestock market. To fill the emptiness of the waiting, the women who have remained behind in the camp seek recourse in different divining techniques available to them for receiving news of those far away, such as divination by dreams or asăwad (literally, 'vision', 'view' or 'regard', from the root 'SWD' of the verb 'to look'), to which this poem refers.

Before discussing the use of dreams for divination among the Tuareg, it should be recalled that mantic techniques are numerous in this society; in this regard, of particular interest is divination by reading signs in the sand, referred to as igazăn, as well as by observing the winding of the viper, which the Tuareg refer to as tachilt or tachchelt. This practice assumes that the reptile can be interrogated using divining formulas.

According to Virolle-Souibes (1995), divination with the aid of a mirror or other reflective surface, called elehen, is closely linked to the theme of waiting. One fills a basin, which one then exposes to moonlight in order to read on the surface of the water images of those far away. This technique is also utilized by pregnant women to reveal the gender of their unborn child. And there are also more elaborate and collective manifestations: women build a tent or a hut away from the light and enter every night with a mirror, after having withdrawn with Islamic talismans. Outside the tent, others sing and play, as in possession rituals called goumaten.

Omens play a primary role and, when they are solid - for instance, when one sees three gazelles or two crows in the morning - they are referred to as tekoubbirt. Presages also involve natural elements (lightning and thunder signifying the anger of angels, for instance) or the aspect or colour of flames and the manner in which certain substances burn.

The Tuareg also practise a form of divination via gravestones; this belongs to practices found across the Mediterranean basin that are referred to as istikhara in the Muslim world. The practice of istikhara consists of reciting a special prayer while waiting for a dream to bring a response and sleeping beside the tomb of a Muslim cleric (aneslem, which is often translated as marabout). In my fieldwork, I found this consultation of graves in Abalak (Niger) and in Tamanrasset (Algeria), where it consisted of praying in the afternoon (for women) or at night (for men) by the graves of Muslim clerics or dead members of the family. Other interlocutors in Mali, both in Kel Ansar (Timbuktu) and Idnan (Kidal), confirmed that such practices still take place, and are intended 
both for advice on future action and for help in interpreting dreams that might clarify past events, such as betrayal by friends. ${ }^{1}$

Although in Tuareg society the ability to see the dead in dreams is dispensed equally to both sexes, consulting the dead for divinatory ends is considered a practice to be performed in public by women but with discretion and in private by men. As we shall see in the next section, men who communicate in dreams are not uncommon among the Tuareg, and they also belong to the category of poets.

Studying Tuareg modalities for frequenting dead poets - which even go as far as erecting posthumous cults around major literary figures - as well as the lasting legacy of poets allows us to better understand the role of the vision of a deceased poet and his ability to transmit verses in dreams.

After this necessarily incomplete overview of mantic techniques, let us now return to the woman poet's poem cited above, which recounts a dream as well as giving the implicit interpretation of that dream by Tâti oult Ourzîg. The author dreamed about a camel and her beloved; the animal was in the midst of a group of other camels. Was the camel shackled by a leash, or was its movement restrained by being surrounded by the other camels? Or were they all tied together? The frequency of dreams in which it is difficult to walk, or in which one is flying or being pursued, ${ }^{2}$ has already been noted in my fieldwork among Tuareg refugees from Mali in Senegal, Niger and France.

The dream about Aghenennas being prevented from coming home is interpreted by Tâti oult Ourzîg, as is the case for the majority of Tuareg dreams, in an antonymic way (for instance, if one dreams of laughing, one dies, and so on). In the same fashion, dreaming of Aghenennas blocked on the path of return actually signifies that he is on his way back home. For this reason, the woman poet rises early in the morning to climb up onto a dune and look out over the vast horizon. Upon not seeing her beloved (not actually named, out of a woman's modesty and superstition, but mentioned through the name of his camel), she tells herself that the dream fooled her.

I myself discovered, in 2006, a poem about dreams by the woman poet Chadi, a nomad from the Gougaram region, to the north of Niger (Dragani 2012). The poet was filmed in the process of reciting a poem in which she related a dream she had in the 1990s during the Tuareg rebellion in the north of Niger (and in the area of Gougaram, where she is from). In her dream, Chadi saw her brothers return after fighting the FAN (Forces armées nigériennes, or Armed Nigerien Forces). The brothers comfort and reassure her, telling her not to be afraid because they are building a house where she will always be sheltered, and where she will no longer have to be afraid of enemy reprisals. Chadi did not interpret the dream in her poem, nor for me directly, because for any Tuareg audience as well as for any informed Westerner, the allusion to the construction of a state where the Tuareg can finally live for eternity is obvious.

\footnotetext{
${ }^{1}$ Practices similar to those used today have been noted by authors including Duveyrier (1864: 415 ) and de Foucauld, who spoke of this women's manner of communicating with the dead (de Foucauld and Motylinski 1984 [1922]; Nicolaisen 1961).

${ }^{2}$ Additionally, being blocked somewhere against one's will - for example, by a bus running late or an accident - is often blamed on a spirit or sorcerer. Legends abound about planes unable to take off despite their engines being in working order, because a genie wanted to delay a given passenger. Once this passenger got off, the plane was able to depart.
} 
As regards the presence of the dream theme in women's poetry, current research has led us to formulate the hypothesis that the dream is more frequently present in women's work than in men's.

This is supported by a contemporary poem shared via a social network by a young Tuareg woman living in France. In 2014, Lalla Wallet Elbecher posted a poem on Facebook. The poem bolsters my thesis that the dream is a theme more specifically female than male, and one that relates to different practices involving the 'public' graveside consultation of the dead, as well as to 'dream quest' by retreat. Presented below a photograph of the female members of her family, dressed in elegant alecho (indigo) fabric, Wallet Elbecher's verses serve as a commentary on the difficult situation facing refugees from northern Mali in the wake of the events that inflamed the region in 2012 and 2013: namely, the declaration of independence of the state of Azawad and its subsequent military occupation by Islamist groups. A conflictual situation already existed in this region, notwithstanding the signing of peace accords. The verses were written in French, and are marked by some errors, but I have translated them directly into English:

I watch you from a distance.

I see you in my dreams once my eyes are closed,

In these faraway deserts,

I am amidst you my sisters,

I watch you from a distance,

I am the spectator of your immense suffering

I watch you from a distance, powerless in the face of your unhappiness.

And this is the root of my profound sorrow.

Significantly, the endurance in the shared memory of male poets and their works is much more pronounced than that of the female poets. Women's poetry is sparsely documented because of the masculinization of female voices by indirect address that is, their work appearing under the names of male recitants - and because of the invisibility of performances by female poets out of fear of the 'evil eye' and the 'bad mouth' (gossip) or of 'radical' Islam (Dragani 2015).

The creation and transmission of literary memory is in effect subject to the strictures of social codes. While female identity is esteemed in Tuareg society, which does not reduce women to their reproductive role or depict them as submissive and docile, nevertheless the 'canonical author', assured by tradition of the transmission of his work post-mortem, is male; he may even be of the lowest rank as long as he is male. In contrast, the doors of recognition and posterity are bolted shut to women.

Assembling a collection of women's poems - as I have already started to do will allow me to verify the hypothesis that the dream is a theme more frequently addressed by women. What lends credence to this hypothesis is that, in this society, women's practices are opposed to men's practices in the public sphere. But although men and women reveal themselves to be different, in reality oneiric attitudes can traverse both gender and class lines.

During my research in Agadez (Niger), I observed the interaction between mothers and children, when young mothers play the violin with their baby on their chest and shoulder. It is obvious from the observation of this activity that 
the children are gradually made aware of the practice of the instrument. Children with violinist mothers understand not only how a violin is constructed but also the airs it plays, and they can even play the instrument themselves, regardless of whether they perform in public.

Likewise, women are schooled in the art of the verse and compose in verse, but they do not recite publicly. Similarly, young girls from the dominant classes in Abalak are sent as teenagers to observe and aid servants when they are cooking, even though, in reality, they will never be asked to cook. When travelling, if no servant is available, the husband or another male member of the family will take care of the cooking, out of chivalry or as a principle of honour. 'We would all rather kill ourselves than see our wives take on manual labour, such as housekeeping tasks,' an interlocutor tells me. Thus, these adolescent apprenticeships are more about mastering a subject in order to more effectively direct the staff, with the mistress of the house assuring the amagaru, or that guests will be received in a sumptuous manner - to the extent that the household's resources permit.

At the same time, young sons of 'nobles' are dispatched to follow shepherds from modest families to learn the secrets of shepherding, even if they themselves will never tend the herd. By contrast, in Tuareg literature there are instances in which slaves have become famous poets, such as Ifellan in the Azawagh region, whose poems I have collected and are preserved by the elder Abdourakhmane in Abalak.

These gender and class differences apply to the different practices for both the 'public' consultation of the dead and the 'dream quest' in this society. The gift of dreaming of the dead and the act of sleeping on their gravestones is as likely to be found in women as in men; the difference is that, in a certain sense, women are authorized to sleep or pray by the graves of woman saints from the clerical group Kel Aghlal in a more visible way than men.

\section{Contemporary attitudes towards sleeping and dreaming}

During fieldwork in Abalak and in Djebock (Mali), I observed that rural communities and nomadic groups do not think of night (ehod) as an uninterrupted period of repose. Night is a propitious occasion for single adults - and for married adults who take advantage of the absence of their travelling spouses - to undertake discreet visits that must be over by dawn. For the male heads of families, night is also punctuated by guard duty, watching over the camp in anticipation of potentially dangerous situations and menaces.

People wrap themselves in Libyan or Algerian blankets ${ }^{3}$ or even envelope their faces in their chèche if they are sleeping in a public place as opposed to a private

\footnotetext{
${ }^{3}$ The globalized circulation of consumer goods means that numerous products arrive from elsewhere, such as blankets from the Maghreb and incense and perfume from Mecca (considered sacred) or from Yemen. Like customs for welcoming visitors to their camps, identical or similar sleeping practices are adopted by Tuareg living in Tamanrasset in Algeria and on the frontier with Nigeria. This is not surprising, given that this is a population which assumes and is recognized for having a relatively homogeneous and uniform cultural and linguistic identity. In addition, the Tuareg's concept of distance is not quantified in kilometres and has little resemblance to Western conceptions of space.
} 
home, although even at home they tend to cover their heads to prevent spirits from licking their faces - or, worse still, from having sexual relations with sleeping women. In Abalak and Kidal (Mali), practices intended to defend a wife against spirit invasion and prevent pregnancy include a sleeping position in which the husband covers the flank, hip and thigh of his companion on her right side.

If the 'preferential' Qur'anic sleeping position presupposes that the sleeper is lying prostrate on the right side, then exhaustion can prompt one to fall asleep in a more haphazard manner. Sleeping on the left side is rare: it is a position that is frowned upon by orthodox Islam and indicates that the sleeper has been possessed by a spirit usually referred to as shaitan in Algeria and Mali, an Arab term, or as ag essuf in Niger.

In Tuareg nomadic and pastoral society, the methods employed to induce sleep are directly related to practices for protecting oneself from spirits, and are meant to allow for an inherently noisy environment. Sleep must accommodate itself to the rustling and whispering of one's immediate entourage as well as the intermittent murmurs of the camp's domestic animals. As one interlocutor explained to me:

Some people actually use the ambient sounds to help them go to sleep - even asking those around them to deliberately make noise. Solitude doesn't help you sleep; it creates pondering and insomnia. Being far from the parents and the rest of the family above all provokes nostalgia. You dwell on things before going to sleep, or can't sleep at all. ${ }^{4}$

Some use the radio, and above all the news, to help them nod off; others use cassette recordings of modern or traditional music. Still others resort to taperecorded readings from the Qur'an. In the course of my research, I was often woken in the middle of the night by the sound of the chants of the muezzins, as recorded on mobile phones, in Abalak.

While noise is necessary to fall soundly asleep, the spot chosen to bed down and the presence of agreeable scents are also important. If one is hoping for a dream that will furnish an answer to a pressing question, it is best to find an outdoor area exposed to cool air. Living in a desert, the Tuareg have an aversion to the heat, which they believe is not propitious for 'good' dreams. In periods of cold weather, it is necessary to slip under a thick blanket to have good dreams. For this reason, it is often said that certain seasons, specifically tagrest, or the cold season, are excellent for sleeping. This also relates to conceiving children: during heatwaves, 'the heat is so intense that one wants to push even one's wife away', as one man put it, expressing the same sentiments as many others. ${ }^{5}$

In general, a lack of dreams can indicate bad health or light psychological disturbance, as can nightmares. This applies to a nomadic context but also to refugees in Europe, who often come from rural environments. My sources also underline the presence of numerous child sleepwalkers in the refugee camps in Mberra and in a Niamey refugee camp that I visited recently. As is the case with adult sleepwalkers, waking them up abruptly is likely to provoke a violent reaction.

\footnotetext{
${ }^{4}$ Interview with A., Tamanrasset, 2011.

${ }^{5}$ Interview with K., Abalak, Niger, 2007.
} 
As far as typology is concerned, I concentrated first on assembling a collection of dreams that present a poetic or musical theme, which are discussed below.

In this nomadic society, dream accounts present numerous topographic markers (hills, dunes, stones, wells). We find dreams that refer to a path, dreams about displacements during the herding of animals, dreams involving traces in the soil, dreams of springs and wells encountered on the road, of methods of transport and of animals. These are the dreams of shepherds, pastoral dreams that Tuareg who live in cities also have. Recent urbanization has not altered much in the rural and herding dreams that are the most frequent.

While dreams are a source of information about the future for the majority of my sources, utilizing a dream as a way of interrogating the past seems to be primarily the privilege of Muslim clerics, who do this by lighting incense and reciting formulas invoking the jnun.

When they talk about their dream life, my interlocutors distinguish between insignificant and significant dreams. The latter require a visit to a Muslim cleric, and it is understood that it is wise not to share their contents with one's entourage. In general, predictive dreams are not related to one's entourage but are often confided to a Muslim cleric (aneslem) or a family sage (amghar) for help in interpreting them.

In the category of meaningful dreams, one finds dreams of public exhibition and recent performance. One dreams about things that one has a habit of accomplishing when awake. This category includes dreams about food, erotic dreams, and dreams involving the minutiae of daily living, as well as 'professionally related dreams' linked to the execution of one's métier - the dreams of a shepherd, of a musician, or of a midwife, for example.

Premonitory dreams tend to be the preserve of certain 'types': poets and musicians are notable in this area. For example, a friend dreamt of having a baby with a French woman, and this materialized sometime later. Numerous musician acquaintances have dreamt of a specific house in Europe that they have later seen with their own eyes. ${ }^{6}$ Dreams of obtaining a visa are frequent among young people. My interlocutors admit that an element of auto-suggestion is at play here, and that dreaming of succeeding at something or of obtaining a wish certainly bestows them with the 'courage' to then pursue the steps necessary for the full realization of that dream.

Then there are the 'bad' dreams. 'There are dreams that foretell people's death, sickness, and inauspicious politics which bring a surfeit of evil omens. ${ }^{\prime 7}$ These eventualities can occur when the dream produces images of people laughing, which is reputed to provoke sickness and territorial conflicts or to presage the death of a loved one. One of my respondents said: 'I laughed in my sleep and two days later I learned of the death of my cousin.' ${ }^{8}$ One can also imagine scenes that provoke laughter. A refugee from Goundam encountered in Dakar in 2014 explained this best: 'In my sleep, I see a woman who hits a man, and that makes me laugh; or a child who hits a castle, and that indicates that something dangerous is about to happen. I dream of that a lot.'

\footnotetext{
${ }^{6}$ Travelling in Europe on performance tours of several months, or even living in Europe for several years, does not markedly alter these practices of the Tuareg.

${ }^{7}$ Interview with B., Gao, 2009.

${ }^{8}$ Interview with H., Paris, 2015.
} 
Other frequent categories of anxiety-provoking dreams include those of being chased by a lion or a dangerous person, a monster or a camel:

There are camels which kill and which bite you on the hand ... When camels are in heat they're dangerous; amali is the camel which attacks people - it is in heat and very jealous. If you put yourself between it and the female camel, it will go after you. When the camel is ten years old it becomes dangerous, which is why one castrates it; otherwise its owner would become its first victim. ${ }^{9}$

A crucial question in the context of this article is how dreams about the dead are interpreted. The dream is perceived as the medium of choice for the dead to communicate with individuals and, to a lesser extent, with the group, because the circulation or sharing of the accounts of dreams is subject to the rules of confidentiality and prudence, particularly in choosing who will interpret the dream, such as a sage (amghar) or a marabout (aneslem). In Timbuktu, there are books in Arabic available on dream intepretation. Those who utilize such books, such as Muslim clerics and other men or women who are able to read Arabic, translate them for others into the Tuareg language.

Discussing dreams, particularly dreams about the dead, is not at all anodyne for the Tuareg. In addition, in recent years dreams have become an object of contention due to their possible interpretation and because of currents in reformist Islam; the latter are more and more present in Tuareg regions and they perceive dream interpretation as un-Islamic. Although recognition of the existence of a parallel world or 'double world' - the world of the jnun - is part of Muslim cosmogony, according it too much importance is frowned upon because spirits are considered malevolent or nuisances.

As far as the practice of sharing dreams is concerned, if no one worthy of confidence is available among one's immediate circle, it is better to remain silent about the dream. Sharing it with a gossip or a jealous person can subsequently hinder its realization. It is necessary to recall that we are talking about a society where words are dangerous and in certain cases it is best to be parsimonious with them.

The role played by Muslim clerics in dream interpretation, aided by the burning of reputedly sacred incense from Mecca or Yemen, which can be procured in the region, is remarkable. An interlocutor who can trace his religious lineage to the Kel Ansar, in the Timbuktu region, explained:

The Muslim cleric dreams for you, because he has sleep potions, concoctions which come from Saudi Arabia and Yemen. He places these over fire and inhales, and takes your name and the name of your mother and listens to what you tell him. He cuts the throat of an animal to prevent the spirits from harassing him or his sons and his nephews, and the spirits take care of the task. Muslim clerics always smell good and are well-adorned. ${ }^{10}$

Looking at all these elements together, it is clear that a study of the ways in which dreams are discussed - as well as how their discussion is avoided - can provide a window into the wider society and its norms, as can the manner of recounting

\footnotetext{
${ }^{9}$ Interview with A., Idelès, Algeria, 2010.

${ }^{10}$ Interview with T., Paris, 2016.
} 
dreams in a given society and the way in which such accounts are inscribed, or left uninscribed, in public and community settings.

\section{Dreams of poets and oneiric inspiration}

The scope of this article is principally limited to dreams of a poetic character collected from male and female poets and violinists, the latter often doubling as female poets, as I have shown elsewhere (Dragani 2012; 2016).

Before we go any further, it is important to consider the terminology available for analysing inspiration and creation among the Tuareg. Local notions for evoking the experience of poetic inspiration, which is at the heart of social practices because of the relations maintained with the world of the invisible, are varied and change according to local customs. When I was in the field, two terms, one of Arabic origin and the other Tuareg, often occurred on the lips of my interlocutors in Abalak: ilhâm and iggi (in the sense of 'vision'). How exactly do we interpret these vernacular notions?

According to the ethno-linguist Jeannine Drouin (1987: 80), 'iggi designates that which is perceived and understood with a distanced and penetrating vision - a vision that comes from the interior and the private: thus one says "iggi-n wul". Iggi is also the verbalization of aggu, which means 'perceive' or 'perceivable from above', but also 'looking into a mirror'.

First, we need to try to define the sense of the word iggi in its rich polysemy and with all its symbolic and emotional resonances, often depending on the manner in which it is employed. The word conveys a local polysemous concept that has four principal significations. Firstly, it carries a topographic meaning indicating an elevated place, such as a mountain or a hill, referring back in a more general sense to the notion of elevation offered by the flight metaphor and the image of wings that poets employ to refer to their sensations when they are in a state of inspiration. To the extent that, in the second case, iggi thus indicates a metaphor or an implicit sense, it encompasses enigmas (iggităn; plural of iggi), a local literary genre close to eni or a proverb.

Thirdly, the term iggi also has another sense that was underlined by my interlocutors in the field as being the most appropriate to describe experience and inspiration, as they pertain to both vision and introspection. It is perhaps for this reason that it comes close to the dreamlike visions of poets that emerged in our ethnography and that I address more generally in the paragraph below that is dedicated to the dreams of poets. The last signification integrates the domain of recovery in that it indicates recovery from fainting or sobering up after being intoxicated.

I should add that Arabic words are sometimes utilized to designate both the poet and the inspiration itself, at least in the maraboutic scholars, such as those deriving from the marabouts of the Kel Aghlal in Niger or the Kel Ansar in the Goundam region (Mali). This is evident in the case of ilhâm and sh'ir - 'he who feels' - as the poet is 'he who feels'. The ilhâm refers to inspiration received by men who may not be prophets but who are considered inspired (muhaddathûn). Prophets receive inspiration that is qualitatively superior and has priority: that is, 'revelation', which is referred to as wahy.

This leaves us with the use of Arabic in the terminology of the semantic field to describe inspiration and poetry: the poet is referred to as emeshewey in 
Tamashek, 'he who presents with the voice', while in Arabic he is called sh'ir. My sources provide the following etymology for the latter: 'he who feels (in his body)'. The word sh'ir is largely suggested by my Malian Tuareg interlocutors in Timbuktu and Goundam.

The signification of the word sh'ir recalls local theories of poetic inspiration linked to the pairing of 'hot' and 'cold'. This pairing of 'hot' and 'cold' has also been identified among the Tuareg by numerous researchers interested in traditional medicine, food, local psychological conceptions, the saturation of colours and notions relating to travel. In my ethnography, this pairing illustrates, in vernacular theory, the dynamic of the creative process, which is represented as a passage from a 'hot' state of the spirit, nourished by intense emotions, to a state of lightness and freshness, as a consequence of poetic creation (Dragani 2016).

Furthermore, in poetic texts, pyretic metaphors prevail when it comes to describing the internal 'hot' state of the poet (fire, combustion), as well as military metaphors (involving bullet wounds or wounds from lances in which the poet describes himself as a target) and metaphors that are demonic in nature (conjuring visits from Satan or from a spirit, as we shall see below).

The state of 'coolness' manifests itself progressively with the creation of the oeuvre and notably in the post-creative phase, which is not described in the texts. To better understand this phenomenon, we polled some poets who, in the course of our interactions, evoked this 'cold' or 'fresh' state by punctuating their discourses with aquatic metaphors (notably concerning rain) and aerial metaphors (tapping into images of wings and flight). An image the poets use to explain the effect of inspiration on the tormented state of their spirits is that of the 'rain' (ăkonak), which, after having 'refreshed' them, leaves them in a state of lightness, expressed by the image of wings that sprout from the back of the poet. Elsewhere, the verb zow rrwer signifies both 'the wings lifting up' on a bird and goosebumps on a person.

I have noted that, as the fourth sense of the word iggi suggests, poetic practice is linked to the notion of healing, as in numerous other concepts born in the Mediterranean basin. It is thus expressed via a medical metaphor as a 'remedy' (amagal in the dialects spoken in the east of the Tuareg world, or isefrăn in the West), which acts during poetic creation to 'cool down' the detrimental excess of heat that certain sentiments such as nostalgia (esuf) or anger engender (etker), as well as the excess of joyous sentiments (tofalawist).

The notion of creation (axălak, from the root 'XLK', implicated in the word for 'create') as well as a substantive term (taxlsk, which indicates that each being creates as much as the ensemble of human beings does) refer directly back to the divine creation and are not employed, according to my interlocutors, for poetic or artistic creation. This is proved by the fact that taxlsk is used as a surname for God - literally understood as 'he who possesses all of creation'.

For several poets, this change from a 'hot' and insufferable state to a 'fresh' and agreeable one is felt in their bodies through their sensations. In relation to the physical aspect of creation - our fieldwork methodologies privileged a kinetic approach to artistic creation - corporeal manifestations of inspiration appear through tensions and contractions in the body, primarily in the neck, which is perceived as rigid, in the face, through tightened skin, and in an irritated or furrowed forehead.

During poetic composition, and afterwards in the post-creative phase, new physical sensations emerge, such as shivering and the bristling of hair, eyelashes 
and eyebrows, as well as a 'reversing of the skin', a local expression indicating goosebumps.

It is important to point out that not all poems are composed in a 'hot' state, and that the poets themselves say that poems that have truly been inspired are rare, appearing no more than three or four times over the course of a lifetime. Equally, they may be plentiful during one epoch and practically non-existent in another. With regard to inspired poetry, it seems reasonable, based on interviews with interlocutors, to assume that an experienced poet is capable of producing 'poems of circumstance' for any event and at any moment. The following verses, which I collected in 2006 in Abalak, were recited by Mohammed ag Ichek dit Tukha, a poet of the Kel Aghlal group, in homage to an Italian woman who sojourned in Abalak during this period, and is an example of a 'poem of circumstance':

War essen Liya
wir taha ijjihat
Wir taha taraq
adir taha arrawdat
wir taha jabat
wir taha d timisra
kundaba za ataha
sin kel aljanat

\author{
He doesn't know Lia. \\ She's not from around here. \\ There isn't a girl around \\ who can compete with her \\ Not among the unmarried [never married] \\ Not among the divorcees [the married and then divorced]. \\ She must be \\ [among] those who come from Heaven.
}

I also discovered a second type of inspiration, which conforms with the word iggi. This type of inspiration, which is discussed in more detail above, was revealed by my sources, as the texts themselves do not necessarily let the inspiration shine through.

In conclusion, the theme of the dream, present as it is in numerous other literary traditions, is all but absent as a theme in Tuareg oral sources and ancient poetic tradition. This unusual absence, rather than diminishing dreams, in fact shows us the importance that this culture attaches to them. In the manner of that which remains 'unspoken', the dream is related to this taste for things that are powerful and hidden, and that resist interpretation. It should be noted that the Tuareg have a penchant for taking snapshots of unsuspecting sleepers during the day or in the middle of the night, with the aim of making fun of insomniacs (see Figure 1).

The poet makes use of these dreams in the creative process as both triggers for the creative act and as oneiric material to be called upon later (as images or dreamed verses) as content for poems.

Dreams that become part of poetic creation and are considered significant by the dreamers are characterized by abrupt awakenings, which terminate in the composition of a poem while the rest of the entourage is still asleep. What can the poet have seen in the dream that is so disturbing, and that suddenly startled him out of his sleep?

At times, these dreams recall an initial public exhibition or exposure in one's youth. This kind of dream produces nostalgia in the dreamer for people now deceased and for circumstances linked to a faraway past. We should note here that dreams of the dead have a particular status among the Tuareg and that these dreams are not meant to be communicated to one's circle but to a Muslim cleric as soon as one wakes up. 


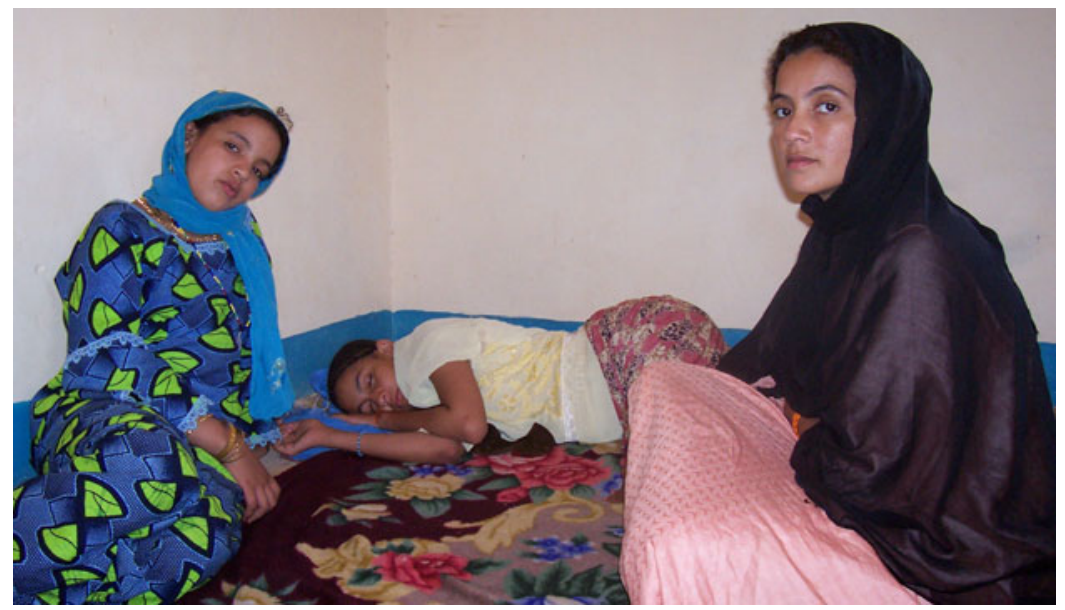

FIGURE 1 Photograph of an unsuspecting sleeper (Abalak, Kel Aghlal, Niger).

One can also dream of the verses of a dead person. Once again, in my exchanges in the field, it was easier for female poets to confess to this kind of contact with the spirit world than for their male counterparts; this reflects a cultural trait rather than providing proof that male poets are less prone to visions while dreaming. The dead poet does not have to be present in an image; he is just as likely to manifest his presence through one of his poems, or through a violin tune that the woman frequently plays and that keeps reappearing in her dreams (Dragani 2012). Despite the fact that the visual cue is the one privileged by the Tuareg and that a visit from the dead in a dream image is taken more seriously, olfactory, tactile, food-related and auditory reminiscences can also evoke the dead poet, his tastes and his aromas, and they can perturb the dreamer as much as his image. This image can seem so real that it gives the living poet the impression that the dead poet or poets she has dreamt of are still alive, making her all the more disappointed when she wakes up to find that this is not the case. Dreams of inspiration or the presence of a dead poet are methods of communication with the dead and with other invisible entities. The vision-dream also makes it possible to distinguish poets from other individuals and other categories of artists who maintain a less direct rapport with the world of the dead.

\section{Acknowledgements}

This article was presented, in a preliminary version, at J. P. Colleyn, E. Jolly, A. Doquet and C. Celius's seminar 'Supports et circulations des arts en Afrique et au de-là' at the Institut des Mondes africaines (IMAf) in Paris. The anonymous reviewers of Africa made valuable comments on the final version. Finally, my gratitude goes to the poets and their entourages, and to my Tuareg informants for my doctoral and post-doctoral research. 


\section{References}

Bastide, R. (1972) Le rêve, la transe et la folie. Paris: Flammarion.

Beradt, C. (1985) The Third Reich of Dreams: the nightmares of nation, 1933-1939. Wellingborough: Aquarian Press.

Burke, P. (1973) 'Histoire sociale des rêves', Annales 28 (2): 329-42

Caillois, R. and G. von Grunebaum (1966) The Dream and Human Societies. Berkeley CA: University of California Press.

Casajus, D. (1989) La tente dans la solitude. La société et les morts chez les Touaregs Kel Ferwan. Cambridge and Paris: Cambridge University Press and Maison des Sciences de l'Homme.

Casajus, D. (1997) Chants touaregs, recueillis et traduits par Charles de Foucauld. Paris: Albin Michel.

Constant, I. (2008) Le rêve dans le roman africain et antillais. Paris: Karthala.

Crapanzano, V. (1975) 'Saints, jnun and dreams: an essay in Moroccan ethnopsychology', Psychiatry 38 (2): 145-59.

D'Andrade, R. G. (1962) 'Anthropological studies of dreams' in F. Hsu (ed.), Psychological Anthropology: approach to culture and personality. Chicago IL: Dorsey Press.

de Foucauld, C. and A. Motylinski (1984 [1922]) Textes touaregs en prose (dialecte de l'Ahaggar). Aix en Provence: Édisud.

Devereux, G. (1951) Reality and Dream: the psychotherapy of a Plains Indian. New York NY: New York University Press.

Dragani, A. (2012) Interno tuareg. Etnografia dei poeti nomadi del Niger. Rome: Aracne.

Dragani, A. (2015) 'Poétesses en marge. Un cas d'interdiction de la parole poétique féminine', Cahiers de Littérature Orale 77-78: 111-42.

Dragani, A. (2016) 'Rêve, sang et maladie. Biographies nocturnes et diurnes de poètes touaregs', Journal des Africanistes 85 (1-2): 358-75.

Drouin, J. (1987) 'De quelques conceptions esthétiques de la parole dans la société touarègue', Journal des Africanistes 57 (1): 77-96.

Duveyrier, H. (1864) L'Exploration du Sahara: les Touâreg du Nord. Paris: Challamel Ainé.

Glowczewski, B. (2016 [1989]) Desert Dreamers: with the Warlpiri people of Australia. Minneapolis MN: Univocal.

Kennedy, J. and L. Lagness (eds) (1981) 'Dreams', Ethos 9 (4) (special issue).

Kilborne, B. (1981) 'Moroccan dream interpretation and culturally constituted defense mechanisms', Ethos 9 (4): 294-311.

Lavie, P. and H. Kaminer (2001) 'Sleep, dreaming, and coping style in Holocaust survivors' in D. Barrett (ed.), Trauma and Dreams. Cambridge MA: Harvard University Press.

Lévy-Bruhl, L. (1935) La mentalité primitive. Paris: PUF.

Mbembe, A. (1991) 'Domaines de la nuit et autorité onirique dans les maquis du Sud-Cameroun, 1955-1958', Journal of African History 32 (1): 89-121.

Nativel, D. (2011) 'Mondes sonores et musiciens des quartiers périphériques de Lourenço Marques (1940-1975)' in F. Rajaonah (ed.), Cultures citadines dans l'océan Indien occidental (XVII-XXI siècles). Paris: Karthala.

Nicolaisen, J. (1961) 'Essai sur la religion et la magie touarègues', Folk 3: 113-60.

Pype, K. (2011) 'Dreaming the apocalypse: mimesis and the Pentecostal imagination in Kinshasa', Paideuma 11: 81-96. 
Radin, P. (1936) 'Ojibwa and Ottawa puberty dreams' in Essays in Anthropology Presented to A. L. Kroeber. Berkeley CA: University of California Press.

Rasmussen, S. J. (2006) Those Who Touch: Tuareg medicine women in anthropological perspective. DeKalb IL: Northern Illinois University Press.

Rasmussen, S. J. (2015) 'An ambiguous spirit-dream and Tuareg-Kunta relationships in rural northern Mali', Anthropological Quarterly 88 (3): 635-63.

Rechtman, R. (1993) 'Rêve, réalité, et expériences traumatiques chez les réfugiés cambodgiens', Cahiers d'Anthropologie et Biometrie Humaine XI (3-4): 259-79.

Schmitt, J.C. (2003) 'Récits et images de rêves au Moyen Âge', Ethnologie Française 4 (33): 553-63.

Stoler, A. L. (2009) Along the Archival Grain: epistemic anxieties and colonial common sense. Princeton NJ: Princeton University Press.

Tedlock, B. (ed.) (1987) Dreaming: anthropological and psychological interpretations. Cambridge: Cambridge University Press.

Virolle-Souibes, M. (1995) 'Divination' in Encyclopédie berbère. Volume 15. Aix-en-Provence: Édisud.

White, L. (2000) Speaking with Vampires: rumor and history in colonial Africa. Berkeley CA: University of California Press.

Wilmer, H. (2001) 'The healing nightmare: war dreams of Vietnam veterans' in D. Barrett (ed.), Trauma and Dreams. Cambridge MA: Harvard University Press.

\begin{abstract}
This article is built upon both an observation and a paradox. The observation is that the dream is nowhere to be found - at least at first glance - as a theme in Tuareg oral sources and ancient poetic tradition. The paradox expresses itself in the visceral relationship poets maintain with the dream, because oneiric inspiration - from the creative and visionary dreams of poets of the past - is pervasive in their work. Using an interdisciplinary approach at the crossroads of psychological anthropology, oral history and the 'archival turn', the article explores the theme of the dream in Tuareg historical sources and in relation to contemporary practices.
\end{abstract}

\title{
Résumé
}

La problématique de cet article repose à la fois sur un constat et sur un paradoxe. Le constat est que le rêve n'est pas présent - à première vue - comme un thème dans les sources orales et dans la tradition poétique. Le paradoxe s'exprime par le fait que les poètes entretiennent une relation étroite avec le rêve car une inspiration onirique - rêves de poètesdécédés - y est attestée. Utilisant une approche interdisciplinaire au carrefour entre anthropologie psychologique, histoire orale et « archival turn » le thème du rêve sera abordé tant dans les sources historiques que dans sa relation aux pratiques contemporaines. 